\section{LETTERS OF GOLD: ENABLING PRIMITIVE ACCUMULATION THROUGH NEOLIBERAL CONSERVATION}

\section{Bram Büscher}

Institute of Social Studies, the Netherlands and Department of Geography, Environmental Management \& Energy Studies, University of Johannesburg, South Africa.

Abstract: In Capital I, Marx wrote that the history of the separation of the producers from the means of production "is written in the annals of mankind in letters of blood and fire" (Marx, 1976: 875). This 'so-called primitive accumulation', or 'accumulation by dispossession' in David Harvey's words, continues unabated. Yet, its framing has changed considerably. Increasingly, capitalists have tried to avoid writing primitive accumulation in 'letters of blood and fire'. Instead, they focus on creating the 'enabling environment' for accumulation by positing neoliberal capitalism as the 'only alternative'. This short essay focuses on nature conservation in Southern Africa to illustrate that this seemingly 'civilized' or 'inevitable' accumulation is none other than the induced self-marginalisation of local people under the 'golden letters' of win-win neoliberal conservation.

\section{Introduction}

In Capital I, Marx wrote that the history of the separation of the producers from the means of production "is written in the annals of mankind in letters of blood and fire" (Marx, 1976: 875). This 'so-called primitive accumulation', or 'accumulation by dispossession' in David Harvey's words, continues unabated. Yet, its framing has changed considerably. Increasingly, capitalists have tried to avoid writing primitive accumulation in 'letters of blood and fire'. Instead, they focus on creating the 'enabling environment' for accumulation by positing neoliberal capitalism as the 'only alternative'. This short essay focuses on nature conservation in Southern Africa to illustrate that this seemingly 'civilized' or 'inevitable' accumulation is none other than the induced self-marginalisation of local people under the 'golden letters' of win-win neoliberal conservation.

\section{Neoliberal Conservation}

Environmental conservation has long been regarded as a bulwark against capitalism. Yet, the last two decades have shown it to be remarkably susceptible to neoliberal intrusion (Heynen et al, 2007). In fact, 'neoliberal conservation' has moved beyond opening up the natural realm to the logic of capital, and as such also beyond the more traditional Marxist political ecology emphasis that nature must be seen as a set of "radically different environments that have been created under several centuries of capitalism" (Harvey, 1998: 332). It is the idea that nature can only be 'saved' through its submission to capital and its subsequent revaluation in capitalist terms. As such, it is fast becoming a vital part of a 'mature and universalised capitalism' (Wood, 1997) of which David Harvey (2006: 93) argues that "there is an aggregate degree of accumulation through dispossession that must be maintained if the capitalist system is to achieve any semblance of stability". While not arguing that capitalism can ever be a 'stable system', it follows that if neoliberal conservation is true to its name, it has to contribute to this 'maintenance'. Obviously, primitive accumulation under the heading of nature conservation is not new and has plenty historical precedents. As Michael Perelman (2007: 51) reminds us, the Game Laws against poaching in $18^{\text {th }}$ century Britain had 'decidedly capitalistic' effects "insofar as they succeeded in accelerating the process of primitive accumulation". Yet, whereas the Game Laws were harshly enforced, 
contemporary conservation claims a more inclusive and cooperative mode of operation.

Neoliberal conservation purports to be sensitive to the needs of conservation and local people but only insofar as they are both mediated and (re)constituted by the logic of the market. Based on previous research on transfrontier conservation (Büscher, 2009) I argue that in Southern Africa, the neoliberal conservation discourse centres on the perceived possibility of continuously increasing the 'multiple wins' necessary to keep conservation legitimate. Phrased differently, conservation in a hypercompetitive, neoliberal public domain increasingly needs to broaden its constituencies and thematic reach in order to remain legitimate. Transfrontier conservation - conservation of areas that straddle the borders of multiple countries - effectuates this by increasing the amount of jurisdictions and 'stakeholders' involved in conservation. Under the banner of 'peace parks', transfrontier conservation advocates reconfigure social and political relations into economic ones, leading to preservation of nature's 'services' for current and future generations, profits for business and local 'line-managers' and cooperation between states.

By far the most influential advocate of peace parks in Southern Africa is the 'Peace Parks Foundation', founded in 1997 by the late billionaire entrepreneur Anton Rupert. According to Rupert, "sinking beneath the weight of war and survival and of exploding populations searching for living space are Africa's designated protected areas, the crown jewels of a tourism industry which has the potential to provide a sustainable way of life". He adds: "poverty stricken Africa desperately needs alternatives to subsistence living, and the creation of jobs from tourism gives these" (PPF, 2000: 2). As in many other neoliberal conservation set-ups, the tourism market is seen as the best way to marry conservation, development and private sector profits (Igoe and Brockington, 2007). The practice of 'nature-based tourism', however, can often more accurately be described as primitive accumulation.

One example should suffice here, drawn from one of the major transfrontier conservation areas (TFCA) in Southern Africa, the Maloti-Drakensberg TFCA between Lesotho and South Africa. Within the TFCA, close to one of the main protected areas and the town of Clarens - a booming tourist town on the South African side - the Royal Maluti company aims to establish a large two-times 18-hole golf estate. The company advertises itself as 'the rare exception' and boasts of possessing "a place of untouched beauty (...) where the mountains meet the sky. A place where you can live, breathe and relax, where freedom and security come together" ${ }^{1}$. In order to obtain this 'place of untouched beauty', however, an environmental impact assessment had to be conducted, the results of which were communicated to local stakeholders in workshops. Attending one such a workshop in January 2007, the following scene unfolded.

The meeting was attended by some 200 people, mostly black people from the Clarens township of Kgubetswana, who could write their names on a register if they were interested in potential jobs at the golf estate once it was operational. They were apprehensive, however, about whether the jobs would actually materialise, as the owner of another nearby golf course had promised the same but never kept his promise. In what can only be described as outright extortion, the Royal Maluti representative remarked that if the communities would allow the process to stall for months or years, his company would go somewhere else and the Clarens area would lose the investment and employment opportunities. This had the intended effect. Hence, even though most local people did not understand the - very technical - presentation, they gave in as the potential prospect for low-wage subservient jobs was still more appealing than the destitute circumstances most people were living in.

In effect, what transpired was that local people were induced into further self-marginalisation by the threat of the company leaving and taking the employment opportunities with them. Simultaneously, they and other local people, especially from across the border in Lesotho, would be further cut of from the land. While officially private farm-land, much of it was de facto used as commonage land, where people grazed their livestock and obtained other resources, such as reeds for weaving. Hence, who was to 'live, breathe and relax' in this space all of a sudden became much more narrowly and

1. See: http://www.royalmaluti.com. 
unequally defined, favouring extra-local golf enthusiasts over locals seeking subsistence. Yet, this is not how this scene is generally interpreted. A local newsletter reported that "a project of this magnitude will most certainly have a positive impact on low skilled communities, who will find an abundance of work either temporarily or permanently". ${ }^{2}$ And while the staff of the TFCA project disagreed with Royal Maluti's methods, they were more concerned with extending the 'employment benefits' to the Lesotho side, rather than stopping the development or negotiating access to the land. After all, one of the transfrontier intervention's key objectives was to help develop the right 'enabling environment' within which private capital could be attracted to help secure the conservation of environmental services and provide jobs through tourism. Glassman (2006: 620) refers to this as the stimulation of primitive accumulation through 'extra-economic political 'interventions'. What is really going on, then, is poignantly described by Mark Dowie, in his recent book on 'conservation refugees':

Market-based solutions, which may have been implemented with the best of social and conservation intentions, share a lamentable outcome, barely discernable behind a smokescreen of slick promotion. In almost every case, indigenous people are moved into the lowest end of the money economy, where they tend to be permanently indentured as park rangers (never wardens), porters, waiters, harvesters, or, if they manage to learn a European language, ecotour guides (Dowie, 2009: xxvi).

On top of this, people are further 'weaned' of the land and its resources; becoming dependent on an industry they have no control over (Dressler and Büscher, 2007).

\section{Conclusion}

Under neoliberal conservation, letters of gold have not replaced 'blood and fire'. Yet, the 'thick smokescreen of slick promotion' does make this reality increasingly less discernible. The Royal Maluti website does not speak of the local, poor residents and the way they were

2. EISH news, une 2007, volume 2. Retrieved from www.eish-news.com. Last viewed: 7 June 2009. coerced. Instead they focus on how this 'densely developed estate' retains $73 \%$ of the property in "its natural state as a habitat for birds, plants, and wildlife". ${ }^{3}$ The letters of gold literally dispose of the experiences of nearby township dwellers and the rural communities across the border in Lesotho as well as their access to what has long de facto been used as commonage land for grazing and other resources. Neoliberal conservation further stimulates these types of experiences and inscribes them into beautifully formulated win-win policies. Induced self-marginalisation through lowwage subservient jobs is marketed as equally valuable as large private profits. Under conditions of neoliberalism, conservation is increasingly turning out as a powerful force for continued primitive accumulation, further cementing the idea that nature can only be 'saved' through and by capitalism.

Acknowledgements Thanks to Linda Herrera, Murat Arsel, Marc Auerbach and all involved in and attending a panel on primitive accumulation at the 2009 AAG for valuable comments, suggestions and debate.

\section{References}

Büscher, Bram (2009). Struggles over Consensus, AntiPolitics and Marketing. Neoliberalism and Transfrontier Conservation and Development in Southern Africa. PhD. dissertation, Vrije Universiteit Amsterdam.

Dowie, M. (2009). Conservation Refugees. The HundredYear Conflict between Global Conservation and Native Peoples. MIT Press, Cambridge.

Dressler, W. and B. Büscher (2008). Market Triumphalism and the so-called CBNRM 'crisis' at the South African Section of the Great Limpopo Transfrontier Park. Geoforum 39, 1: 452-465.

Glassman, J. (2006). Primitive Accumulation, Accumulation by Dispossession, Accumulation by 'Extraeconomic' Means. Progress in Human Geography 3, 5: 608-625.

Harvey, D. (1998). What's Green and Makes the Environment Go Round? In F. Jameson and M. Miyoshi, eds., The Cultures of Globalization. Durham: Duke University Press, pp. 327-355.

Harvey, D. (2006). Spaces of Global Capitalism. Towards a

3. http://www.royalmaluti.com/\#. Last viewed: 7 june 2009. 